\title{
Moringa oleifera inhibits growth of Candida spp. and Hortaea werneckii isolated from Macrobrachium amazonicum prawn farming with a wide margin of safety
}

\author{
Moringa oleifera inibe o crescimento de Candida spp. e Hortaea werneckii isoladas da criação de
} camarões Macrobrachium amazonicum com ampla margem de segurança

\author{
Marcos Fábio Gadelha Rocha ${ }^{\mathrm{I}, \text { II }}$ Lucas Pereira de Alencar, II Raimunda Sâmia Nogueira Brilhante ${ }^{\mathrm{II}}$ \\ Jamille de Alencar Sales, II Yago Brito de Ponte ${ }^{\mathrm{III}}$ Pedro Henrique de Aragão Rodrigues ${ }^{\mathrm{II}}$ \\ Célia Maria de Souza Sampaioi, III Rossana de Aguiar Cordeiro ${ }^{\text {II }}$ \\ Débora de Souza Collares Maia Castelo-Branco ${ }^{\mathrm{II}}$ Francisco Carlos de Oliveira $^{\mathrm{IV}}$ \\ Francisco Geraldo Barbosa ${ }^{\text {IV }}$ Carlos Eduardo Cordeiro Teixeira ${ }^{\text {II }}$ \\ Manoel de Araújo Neto Paiva ${ }^{\text {I, II }}$ Tereza de Jesus Pinheiro Gomes Bandeira ${ }^{I I}$ \\ José Luciano Bezerra MoreiraII José Júlio Costa SidrimI
}

\section{ABSTRACT}

This study aimed to evaluate the antifungal activity of M. oleifera extracts against fungi isolated from farmed prawns and test the toxicity of the extracts on larvae of Macrobrachium amazonicum. The ethanol extracts of pods, seeds, leaves, stems and flowers and chloroform extract of flowers of M. oleifera were tested against 14 strains of Candida spp. and 10 strains of Hortaea werneckii isolated from farming water and the digestive tract of $\boldsymbol{M}$. amazonicum. Antifungal activity was determined by microdilution, based on the M27-A3 and M38-A2 CLSI documents. Toxicity was evaluated by exposing larvae of M. amazonicum at concentrations between 10-1000mg $\mathrm{mL}^{-1}$, counting dead larvae (CL50) after 24 hours. The best results were verified with the chloroform extract of flowers, acting against all tested strains, with MICs ranging from 0.019 to $2.5 \mathrm{mg} \mathrm{mL}^{-1}$. Ethanol extracts of leaves, flowers and seeds acted against 22/24, 21/24 and 20/24 strains, respectively. The extract of pods was only effective against strains of Candida spp. (14/24) and extract of stem only against four strains of $\boldsymbol{H}$. werneckii (4/24). Extracts of seeds, flowers (chloroform fraction), stems and leaves showed low or no toxicity, whereas extracts of pods and flowers (ethanol fraction) showed moderate toxicity. Thus, the antifungal activity of these extracts agaisnt Candida spp. and $\boldsymbol{H}$. werneckii was observed, a wide margin of safety for larvae of M. amazonicum, demonstrating to be promising for the sustainable management of effluents from M. amazonicum farming.

Key words: aquaculture, Fungi, prawn, Moringa oleifera, antimicrobial

RESUMO

Este estudo teve como objetivo avaliar a atividade antifúngica de extratos de M. oleifera frente a fungos isolados de camarões, cultivados em água doce, e testar a toxicidade dos extratos em larvas de Macrobrachium amazonicum. Os extratos etanólicos de vagens, sementes, folhas, caules e flores e o extrato clorofórmico de flores de M. oleifera foram testados contra 14 cepas de Candida spp. e 10 cepas de Hortaea werneckii isolados da água de cultivo e do trato digestório de M. amazonicum. A atividade antifúngica foi determinada por microdiluição, com base nos documentos M27-A3 e M38-A2 do CLSI. A toxicidade foi avaliada por exposição das larvas de M. amazonicum a concentrações entre $10-1000 \mathrm{mg} \mathrm{mL}^{-1}$ dos extratos, realizando contagem de larvas mortas (CL50), após 24 horas. Os melhores resultados foram verificados com o extrato clorofórmico de flores, agindo frente a todas as cepas testadas, com concentrações inibitórias mínimas variando entre 0,019-2,5 $m g \mathrm{~mL}^{-1}$. O extrato etanólico de folhas, flores e sementes agiu ante 22/24, 21/24 e 20/24 cepas, respectivamente. O extrato de vagens foi eficaz contra cepas de Candida spp. (14/24) e o extrato de caule apenas contra quatro cepas de $\boldsymbol{H}$. werneckii (4/24). Os extratos de sementes, flores (fração clorofórmica), caules e folhas apresentaram baixa ou nenhuma toxicidade, enquanto que extratos de vagens $e$ flores (fração etanólica) apresentaram toxicidade moderada. Assim, observou-se atividade antifúngica dos extratos em Candida spp . e $\boldsymbol{H}$. werneckii com uma ampla margem de segurança para as larvas de M. amazonicum, demonstrando ser promissor para o manejo sustentável dos efluentes do cultivo de M. amazonicum.

Palavras-chave: aquacultura, fungos, camarão, Moringa oleifera, antimicrobianos.

\section{INTRODUCTION}

Freshwater prawn farming has been reported to have low environmental impact, making

\footnotetext{
IPrograma de Pós-graduação em Ciências Veterinárias, Faculdade de Veterinária, Universidade Estadual do Ceará (UECE), Fortaleza, CE, Brasil.

IIPrograma de Pós-graduação em Microbiologia Médica, Centro Especializado em Micologia Médica, Universidade Federal do Ceará (UFC), Rua Coronel Nunes de Melo, s/n, Rodolfo Teófilo, 60430-270, Fortaleza, CE, Brasil. E-mail: brilhante@ufc.br.*Autor para correspondência.

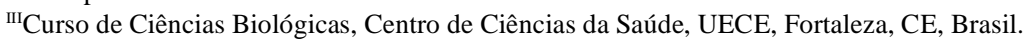

${ }^{\mathrm{IV}}$ Departamento de Química Orgânica e Inorgânica, UFC, Fortaleza, CE, Brasil.
} 
it a more sustainable alternative to the production of these crustaceans, when compared to the marine counterpart. This activity leads to lower disease incidence in animals, simplified hatching, production systems compatible with small farms and lower environmental impact (MACIEL \& VALENTI, 2009). However, freshwater farming is not free of environmental impacts and other problems, especially in intensive production systems. Among these problems, there are land use competition, reduction of biodiversity due to discharges from cultivation and agrochemical effluents, which lead to an increase in the populations of phytoplankton and bacteria, which are commonly isolated from cultivation areas and effluents, including bacterial strains that present antimicrobial resistance (MACIEL \& VALENTI, 2009; BRILHANTE et al., 2011; REBOUÇAS et al., 2011).

Among the most commonly isolated microorganisms from aquaculture, bacteria of the genera Vibrio and Aeromonas and fungi of the genus Candida spp. are the most commonly recovered, colonizing various niches, including microbiota of animals and water during the different stages of production. Moreover, the fungus Hortaea werneckii has mainly been isolated in environments with salinity between 3000 and $7500 \mathrm{mg} \mathrm{L}^{-1}$ (PETROVIC et al., 2002; SAHUL HAMEED et al., 2003; MEDEIROS et al., 2008) and has already been reported in water from Macrobrachium amazonicum farming (BRILHANTE et al., 2011). Other studies have demonstrated the pathogenicity of fungi isolated in aquaculture, such as Candida spp. and $\boldsymbol{H}$. werneckii, to livestock, humans and other animals (PILLAI \& BONAMI, 2012).

Therefore, attention should be paid to the potential environmental impacts of discharge of untreated wastes from shrimp farming, by formulating actions to reduce the degree of eutrophication and the load of microorganisms in wastewater. In this respect, due to the coagulant action of Moringa oleifera seeds, researchers have studied the use of this plant to treat water for human consumption. The findings show that it acts more stably in a broader range of water $\mathrm{pH}$ than that of aluminum sulfate, at a significantly lower cost (OKUDA et al., 2001; SÁNCHEZ-MARTÍN et al., 2010). Similarly, $\boldsymbol{M}$. oleifera has been studied for direct application in water treatment by flocculation and sedimentation, eliminating the turbidity, suspended particles and microorganisms (CHUANG et al., 2007; SÁNCHEZMARTÍN et al., 2010; DAS et al., 2012). In a recent study, our group showed the antifungal activity of the flower extract of $\boldsymbol{M}$. oleifera against $\boldsymbol{C}$. albicans and Microsporum canis strains from dogs (ROCHA et al., 2011), suggesting the possibility of applying this product to control yeast and filamentous fungi growth associated with M. amazonicum farming.

Thus, this study aimed to determine the antifungal activity of $\boldsymbol{M}$. oleifera extracts on strains of Candida spp. and $\boldsymbol{H}$. werneckii isolated from farming of M. amazonicum, as well as to evaluate the toxicity of the extracts on larvae of this prawn.

\section{MATERIAL AND METHODS}

\section{Extracts}

The extracts were obtained from specimens of M. oleifera from Fortaleza, Ceará, and were provided by the Chemistry Department of Federal University of Ceará, Fortaleza, Ceará. Different parts of the plant were dried in a kiln at $40^{\circ} \mathrm{C}$, and then subjected to three successive extractions by cold maceration with ethanol at intervals of $24 \mathrm{~h}$, generating ethanol extracts of Moringa stems (Ethanol Stem Extract), leaves (Ethanol Leaf Extract), flowers (Ethanol Flower Extract), pods (Ethanol Pod Extract) and seeds (Ethanol Seed Extract). Likewise, Moringa flowers were dried at $40^{\circ} \mathrm{C}$ and then subjected to three successive extractions by cold maceration with chloroform PA at $24 \mathrm{~h}$ intervals, producing chloroform extract of Moringa flowers (Chloroform Flower Extract). After filtration, the corresponding solvents were evaporated under reduced pressure on a rotary evaporator, leaving only the concentrated constituents extracted from the plants (ROCHA et al., 2011).

Tested strains

Fourteen strains of Candida spp. and 10 strains of $\boldsymbol{H}$. werneckii were used, which were recovered as described by BRILHANTE et al. (2011). Seven isolates of Candida spp. were recovered from the digestive tract of $\boldsymbol{M}$. amazonicum from the natural environment (one $\boldsymbol{C}$. ciferrii; three $\boldsymbol{C}$. famata; one $\boldsymbol{C}$. guilliermondii; one $\boldsymbol{C}$. parapsilosis; one $\boldsymbol{C}$. tropicalis) and the other seven isolates were obtained from hatchery water, with salinity of $4 \%$ (two $\boldsymbol{C}$. ciferrii; three $\boldsymbol{C}$. famata; one $\boldsymbol{C}$. guillermondii; one C. parapsilosis). The isolates of $\boldsymbol{H}$. werneckii were obtained from hatchery water with salinity $4 \%$. These strains were obtained from the fungal collection of the Specialized Medical Mycology Center (CEMM) of the Federal University of Ceará (UFC). For this study, the strains were reactivated and the purity of the colonies was verified on the chromogenic medium Candida HiCrome Differential Agar (HiMedia 
Laboratories, India) (BRILHANTE et al., 2011). The strains were subcultured on potato dextrose agar and kept at $25^{\circ} \mathrm{C}$. For quality control, the strains $\boldsymbol{C}$. parapsilosis ATCC 22019 and C. krusei ATCC 6258 were included in the susceptibility assays.

Antifungal susceptibility testing

Each extract was diluted in a 1:2 ratio in dimethyl sulfoxide (DMSO). Subsequently, each extract was shaken in vortex to facilitate dilution and further diluted with RPMI to a concentration of $20 \%$ DMSO. Thus, during the susceptibility assays, the highest concentration of DMSO did not exceed 5\% (ROCHA et al., 2011).

The minimum inhibitory concentration (MIC) of the Moringa extracts against the Candida genus and $\boldsymbol{H}$. werneckii were determined through broth microdilution, according to the documents M27-A3 (CLSI, 2008a) and, M38-A2 (CLSI, 2008b), with some modifications to include the use of the extracts of M. oleifera, as described by ROCHA et al. (2011). Each plant extract was evaluated in the concentration range from 0.01 to $5 \mathrm{mg} \mathrm{mL}^{-1}$. The control drugs amphotericin $\mathrm{B}$, itraconazole and fluconazole were tested in concentration ranges from 0.031 to $16 \mu \mathrm{g} \mathrm{mL}^{-1}, 0.031$ to $16 \mu \mathrm{g} \mathrm{mL}^{-1}$ and 0.125 to $64 \mu \mathrm{g} \mathrm{mL} \mathrm{m}^{-1}$, respectively. The microdilution assay was performed in 96-well plates in a total volume of $200 \mu \mathrm{L}$. The plates were incubated at $35^{\circ} \mathrm{C}$ and were read after 48 hours. All tests were performed in duplicate. The readings were performed by visual comparison with the control of fungal growth without extract.

The MIC for itraconazole, fluconazole and the tested extracts was considered as the lowest concentration that caused a $50 \%$ reduction in fungal growth compared with growth control, while for amphotericin B, the MIC was defined as the lowest concentration at which complete inhibition $(100 \%)$ of fungal growth was observed (ROCHA et al., 2011). The extracts with MICs greater than $5 \mathrm{mg} \mathrm{mL}^{-1}$ in this research were considered as producing no growth inhibition.

\section{Acute toxicity}

The toxicity of the six extracts was tested according to the method described by MEYER et al. (1982) and RAMOS et al. (2009), with adaptations for the species $\boldsymbol{M}$. amazonicum. First, larvae of $\boldsymbol{M}$. amazonicum were transferred to water with $4 \%$ salinity and were kept under artificial white light and abundant aeration for 24 hours, until the development of the second larval stage. The larvae were then divided into three experimental groups (each group tested in triplicate). In group 1 the larvae were exposed to the extracts at concentrations of 10, 50, 100, 300, 500 and $1000 \mathrm{mg} \mathrm{mL}^{-1}$; in group 2 they were exposed to the same concentrations of DMSO as group 1, to verify the toxicity of the diluent; in group 3 , the larvae were subjected to sham treatment, applying the same treatment conditions, but without the use of extract or diluent. The tests were performed in beaker containing $50 \mathrm{~mL}$ of test solution and 10 larvae of $\boldsymbol{M}$. amazonicum. The beakers were incubated at $29^{\circ} \mathrm{C}$ under white light for 24 hours, after which the dead larvae were counted to determine the $\mathrm{LC}_{50}$ (lethal concentration for $50 \%$ of larvae). As recommended by RAMOS et al. (2009), $\mathrm{LC}_{50}<80 \mathrm{mg} \mathrm{mL}^{-1}$ was considered highly toxic; $\mathrm{LC}_{50}$ from $80 \mathrm{mg} \mathrm{mL}^{-1}$ to $250 \mathrm{mg} \mathrm{mL}^{-1}$ moderately toxic; and $\mathrm{LC}_{50}>250 \mathrm{mg} \mathrm{mL}^{-1}$ slightly toxic or not toxic. The results were expressed as mean \pm standard error and the significance between control and each extract was tested using Student's t-test $(\mathrm{P}<0.05)$ (KAVITHA et al., 2012). For data analysis, the Trimmed Spearman-Karber statistical software (version 1.5) was used.

\section{RESULTS}

The Chloroform Flower Extract showed activity against all tested strains from prawn farming, with MICs ranging from 0.019 to $2.5 \mathrm{mg} \mathrm{mL}^{-1}$. The Ethanol Leaf Extract showed MICs ranging from 0.156 to $2.5 \mathrm{mg} \mathrm{mL}^{-1}$, with action against all the strains of Candida spp. isolated from water, all the strains of $\boldsymbol{H}$. werneckii and against 5/7 isolates from prawns. The Ethanol Flower Extract showed activity against all the strains of Candida spp. from water, all strains of $\boldsymbol{H}$. werneckii and 4/7 of Candida spp. strains from prawns, with MICs ranging from 0.156 to $2.5 \mathrm{mg} \mathrm{mL}^{-1}$. The Ethanol Seed Extract exhibited MIC between 0.3125 to $2.5 \mathrm{mg} \mathrm{mL}^{-1}$, with activity against all strains of $\boldsymbol{H}$. werneckii and against $6 / 7$ strains of Candida spp. from prawns and 4/7 strains of Candida spp. from water (Table 1). Overall, there was antifungal activity of the extracts from different parts of the plant against the strains isolated from prawns, except for the Ethanol Pod Extract, which was effective only against the strains of Candida spp. (14/24), and Ethanol Stem Extract, which only showed activity against four strains of $\boldsymbol{H}$. werneckii (4/24).

The Ethanol Seed Extract, Ethanol Leaf Extract, Ethanol Stem Extract and Chloroform Flower Extract showed low or no toxicity; while Ethanol Pod Extract and Ethanol Flower Extract showed moderate 
Table 1 - Minimum inhibitory concentration (MIC) of classical antifungal drugs and Moringa oleifera extracts against Candida spp. and $\boldsymbol{H}$. werneckii.

\begin{tabular}{|c|c|c|c|c|c|c|c|c|c|c|}
\hline \multirow[b]{2}{*}{ Source } & \multicolumn{4}{|c|}{ 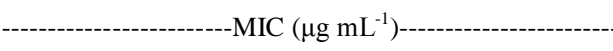 } & \multicolumn{6}{|c|}{ - } \\
\hline & Species & AMB & FLZ & ITZ & $\mathrm{EPoE}$ & $\mathrm{ESeE}$ & ELeE & EStE & EFlE & CFlE \\
\hline \multirow{7}{*}{ Prawn } & C.ciferrii & 0.5 & $>64$ & $>16$ & 1.25 & n.i. & 2.5 & n.i. & n.i. & 0.625 \\
\hline & C. famata & 0.062 & 32 & 0.25 & 2.5 & 1.25 & 0.625 & n.i. & 2.5 & 0.625 \\
\hline & C.famata & 0.062 & 16 & 4 & 1.25 & 1.25 & 0.312 & n.i. & 1.25 & 1.25 \\
\hline & C.famata & 0.062 & 16 & 0.25 & 0.625 & 1.25 & 0.156 & n.i. & 0.625 & 0.625 \\
\hline & C.guilliermondii & 0.25 & 2 & 0.25 & 2.5 & 1.25 & n.i. & n.i. & 1.25 & 1.25 \\
\hline & C.parapsilosis & 0.25 & 0.25 & 0.125 & 2.5 & 2.5 & n.i. & n.i. & n.i. & 0.625 \\
\hline & C.tropicalis & 0.5 & $>64$ & $>16$ & 2.5 & 2.5 & 2.5 & n.i. & n.i. & 1.25 \\
\hline \multirow{7}{*}{ Water } & C.ciferrii & 1 & 64 & 16 & 0.625 & n.i. & 1.25 & n.i. & 1.25 & 2.5 \\
\hline & C. ciferrii & 0.125 & 32 & 1 & 0.312 & 2.5 & 1.25 & n.i. & 0.156 & 0.039 \\
\hline & C.famata & 0.125 & 16 & 0.062 & 0.625 & n.i. & 1.25 & n.i. & 0.312 & 0.156 \\
\hline & C.famata & 0.125 & 16 & 0.062 & 0.625 & 1.25 & 1.25 & n.i. & 0.156 & 0.039 \\
\hline & C.famata & 0.125 & 16 & 0.062 & 0.625 & 1.25 & 2.5 & n.i. & 0.156 & 0.019 \\
\hline & C.guilliermondii & 0.5 & $>64$ & $>16$ & 1.25 & 2.5 & 1.25 & n.i. & 2.5 & 1.25 \\
\hline & C.parapsilosis & 1 & 1 & 0.125 & 0.625 & n.i. & 2.5 & n.i. & 1.25 & 0.312 \\
\hline \multirow{10}{*}{ Water } & H. werneckii & 1 & 0.5 & 0.125 & n.i. & 0.312 & 1.25 & 1.25 & 2.5 & 1.25 \\
\hline & H. werneckii & 0.5 & 1 & 0.125 & n.i. & 0.625 & 2.5 & 1.25 & 2.5 & 0.625 \\
\hline & H. werneckii & 0.5 & 0.25 & 0.125 & n.i. & 0.625 & 2.5 & n.i. & 2.5 & 1.25 \\
\hline & H. werneckii & 0.25 & 1 & 0.125 & n.i. & 0.312 & 1.25 & n.i. & 1.25 & 1.25 \\
\hline & H. werneckii & 0.25 & 0.5 & 0.062 & n.i. & 0.625 & 2.5 & 1.25 & 1.25 & 1.25 \\
\hline & H. werneckii & 1 & 2 & 0.062 & n.i. & 0.312 & 1.25 & 1.25 & 1.25 & 0.625 \\
\hline & H. werneckii & 0.5 & 16 & 1 & n.i. & 0.625 & 1.25 & n.i. & 2.5 & 1.25 \\
\hline & H. werneckii & 0.5 & 0.5 & 0.031 & n.i. & 0.625 & 1.25 & n.i. & 1.25 & 1.25 \\
\hline & H. werneckii & 0.25 & 4 & 0.25 & n.i. & 0.625 & 1.25 & n.i. & 2.5 & 1.25 \\
\hline & H. werneckii & 0.25 & 0.25 & 0.031 & n.i. & 0.625 & 2.5 & n.i. & 1.25 & 0.625 \\
\hline ATCC & C.krusei & 1 & 32 & 1 & n.i. & n.i. & 2.5 & 0.625 & 0.078 & 2.5 \\
\hline ATCC & C.parapsilosis & 0.5 & 2 & 0.062 & n.i. & 0.625 & 0.625 & n.i. & n.i. & n.i. \\
\hline
\end{tabular}

AMB: amphotericin B; FLZ: fluconazole; ITZ: itraconazole; EPoE: Ethanol Pod Extract; ESeE: Ethanol Seed Extract; ELeE: Ethanol Leaf Extract; EStE: Ethanol Stem Extract; EFIE: Ethanol Flower Extract; CFIE: Chloroform Flower Extract; n.i.: no inhibition.

toxicity, with no statistically significant difference between the $\mathrm{LC}_{50}$ values for the various extracts (Figure 1).

\section{DISCUSSION}

The results of this study demonstrated the antifungal activity of various extracts from different parts of $\boldsymbol{M}$. oleifera against strains isolated from prawn farming. These results corroborate the antifungal activity of the essential oil and crude extracts of seeds, leaves, flowers and stems of Moringa against dermatophyte fungi, Aspergillus spp., Penicillium sclerotigenum, Cladosporium cladosporioides and $\boldsymbol{C}$. albicans (CHUANG et al., 2007; RAHMAN et al., 2008; ROCHA et al., 2011). Based on these previous reports, it was decided to test different parts of M. oleifera to evaluate the distribution of bioactive compounds in this plant. It was prioritized the use of ethanol as solvent for the extraction of bioactive compounds because it is more accessible, less toxic and it extracts polar and apolar substances (FERREIRA-DIAS et al., 2003).

In addition, due to our previous research (ROCHA et al., 2011), the Chloroform Flower Extract was also included in this study in order to further evaluate the antifungal properties of this compound. Similarly to our previous findings (ROCHA et al., 2011), this extract was effective in inhibiting all strains originating from prawn farming. In addition, it was observed that the Ethanol Flower Extract was also effective against the tested fungi, presenting an $87.5 \%$ inhibition rate, as opposed to the $100 \%$ inhibition caused by the Chloroform Flower 


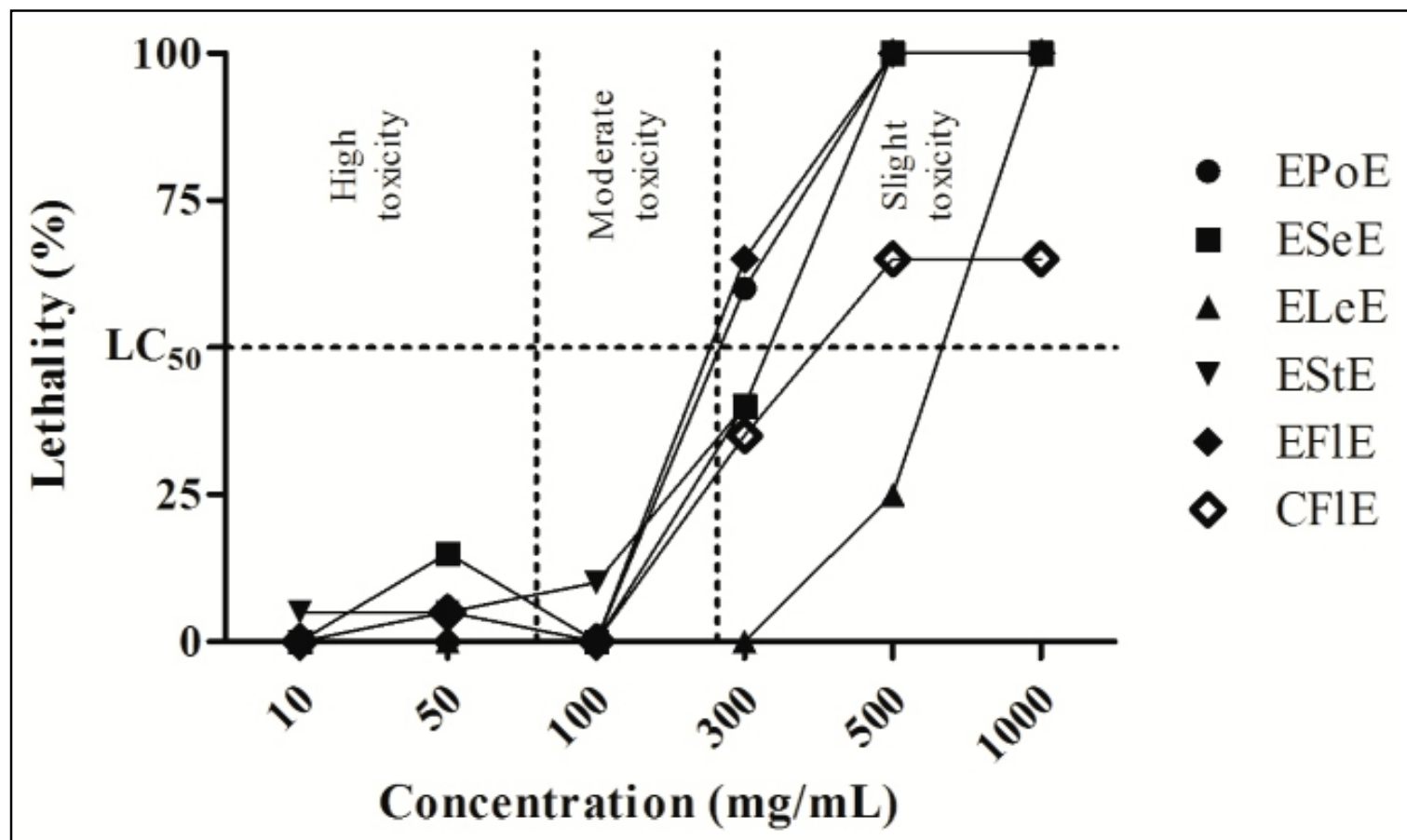

Figure 1 - Lethality of larvae of Macrobrachium amazonicum after 24 hours of exposure to different concentrations of Moringa oleifera extracts. LC50 <80 $\mathrm{mg} \mathrm{mL}^{-1}$ was considered high toxicity; LC50 from $80 \mathrm{mg} \mathrm{mL}^{-1}$ to $250 \mathrm{mg}$ mL-1 moderate toxicity; and LC50>250 $\mathrm{mg} \mathrm{mL}^{-1}$ slight toxicity or not toxic (RAMOS et al., 2009). EPoE: Ethanol Pod Extract; ESeE: Ethanol Seed Extract; ELeE: Ethanol Leaf Extract; EStE: Ethanol Stem Extract; EFlE: Ethanol Flower Extract; CFlE: Chloroform Flower Extract.

Extract. Thus, the results of this study suggest that the bioactive component of flowers can be obtained with chloroform and ethanol, but the chloroform based extraction results in higher concentrations of the bioactive compounds compared to the ethanol counterpart, since the chloroform compound has higher antifungal activity than that reported for the ethanol compound.

The Ethanol Pod Extract was effective against all strains of Candida spp. Due to the importance of the Candida genus in cultivating prawns, this plant portion is also promising for fungal control in prawn farming. On the other hand, this extract did not inhibit any isolate of H. werneckii. The reason for this difference in susceptibility remains unknown, but the species $\boldsymbol{H}$. werneckii is a melanized fungus and it is known that melanin provides protection against several aggressors, including oxidizing agents and antifungal drugs (EISENMAN; CASADEVALL, 2012). The Ethanol Seed Extract and Ethanol Leaf Extract showed activity against more than $80 \%$ of the strains tested. CHUANG et al. (2007) tested raw seed extract and different sub-fractions against dermatophytes and observed different MICs for each type of extract, with the ethyl acetate subfraction presenting the lowest MIC $\left(0.625 \mathrm{mg} \mathrm{mL}^{-1}\right)$ and the aqueous subfraction presenting the highest MIC $\left(10 \mathrm{mg} \mathrm{mL}^{-1}\right)$. As for the leaf extract, CHUANG et al. (2007) found no antifungal activity for crude leaf extract and its sub-fractions, against dermatophytes, while our results showed good inhibitory activity against $\boldsymbol{H}$. werneckii and Candida spp., mainly $\boldsymbol{C}$. famata, which is one of the predominant Candida species recovered from $\boldsymbol{M}$. amazonicum farming (BRILHANTE et al., 2011)

The Ethanol Stem Extract was the extract with the lowest antifungal activity, only being effective against four strains of $\boldsymbol{H}$. werneckii, at the highest end of the tested concentration range, which suggests that ethanol is not a viable solvent to obtain bioactive molecules from the stem of M. oleifera. Similarly, DAS et al. (2012), using the ether-derived stem extract observed no inhibitory effect on six fungal species. On the other hand, RAHMAN et al. (2008), using this herbal component, observed that the chloroform and ethyl 
acetate sub-fractions inhibited fungal growth. There are several studies on the antifungal properties of M. oleifera, using different methodologies to perform the susceptibility assays, making it difficult to compare the previously published data. This is why, in this study, it was sought to standardize the susceptibility assay with Moringa extracts, according to CLSI guidelines.

The Moringa extracts' toxicity against larvae of M. amazonicum was classified according to MEYER et al. (1982) and RAMOS et al. (2009) with adaptations for the target species. In this study, there was no high toxicity in any of the analyzed extracts. Exposure to extracts with low or no toxicity showed average $\mathrm{LC}_{50}$ of $392.07 \mathrm{mg} \mathrm{mL}^{-1}$, while mean $\mathrm{LC}_{50}$ was $238.98 \mathrm{mg} \mathrm{mL}^{-1}$ for moderately toxic extracts. The extracts' toxicity can vary widely among plant parts, depending on the chemicals present in the plant and susceptibility of the target species (RAMOS et al., 2009). As noted by TIWARI \& SINGH (2003), the toxicity of an extract also depends on the solvent used, as observed in this study, where the Ethanol Flower Extract was nearby 1.7 times more toxic than Chloroform Flower Extract, although no statistical difference was detected.

In prawn farming, the animals are subjected to stressful conditions, predisposing them to the emergence of infectious diseases caused by opportunistic pathogens such as Candida spp., which have been described as part of the microbiota and as an infectious agent of $\boldsymbol{M}$. amazonicum (GATESOUPE, 2007; BRILHANTE et al., 2011). Thus, preventive procedures should be adopted to minimize the negative impacts of infectious diseases in the population and the dumping of effluents into the environment. In this context, the perspective of using products from $\boldsymbol{M}$. oleifera in the treatment of wastewater against yeasts and molds in prawn farmingwas pointed to reduce environmental degradation associated with discharge of untreated waste from cultivation.

\section{CONCLUSION}

In this study it was observed that $\boldsymbol{M}$. oleifera extracts have antifungal activity against strains of Candida spp. and $\boldsymbol{H}$. werneckii isolated from cultivation water and prawns, especially the products extracted from leaves and flowers. Moreover, it was found that these extracts have a wide margin of safety for larvae of M. amazonicum, demonstrating to be promising for the sustainable management of effluents from $M$. amazonicum cultivation.

\section{ACKNOWLEDGEMENTS}

This work was supported by the Coordination of Improvement of Higher Education Personnel (CAPES) and Foundation for the Support of Scientific and Technological Development of Ceará (CAPES/FUNCAP; process AE1-0052000650100-11) and by the National Council for Scientific and Technological Development (CNPq; process numbers 307606/2013-9; 504189/2012-3; 562296/2010-7).

\section{REFERENCES}

BRILHANTE, R.S.N. et al. Yeasts from Macrobrachium amazonicum: a focus on antifungal susceptibility and virulence factors of Candida spp. FEMS Microbiology Ecology, v.76, p.268-277, 2011. Available from: <http://onlinelibrary.wiley.com/ doi/10.1111/j.1574-6941.2011.01050.x/abstract>. Accessed: Ago. 08, 2013. doi:10.1111/j.1574-6941.2011.01050.x.

CLINICAL AND LABORATORY STANDARDS INSTITUTE (CLSI). Reference method for broth dilution antifungal susceptibility testing of yeasts. Approved standard. 3ed. Wayne, PA: CLSI, 2008a. CLSI document M27-A3.

CLINICAL AND LABORATORY STANDARDS INSTITUTE (CLSI). Reference method for broth dilution antifungal susceptibility testing of filamentous fungi. Approved standard. 2ed. Wayne, PA: CLSI, 2008b. CLSI document M38-A2.

CHUANG, P.H. et al. Anti-fungal activity of crude extracts and essential oil of Moringa oleifera Lam. Bioresource Technology, v.98, p.232-236, 2007. Available from: <http://www.sciencedirect. com/science/article/pii/S0960852405005286>. Accessed: Ago. 12, 2013. doi: 10.1016/j.biortech.2005.11.003.

DAS, J. et al. In vitro antibacterial and antifungal potentials of petroleum ether extract of Moringa oleifera. Journal of Pharmacology and Toxicology, v.7, p.110-113, 2012. Available from: 〈http://scialert.net/abstract/?doi=jpt.2012.110.113>. Accessed: Ago. 10, 2013. doi: 10.3923/jpt.2012.110.113.

EISENMAN, H.C.; CASADEVALL, A. Synthesis and assembly of fungal melanin. Applied Microbiology and Biotechnology, v.93, p.931-940, 2012. Available from: <http://link.springer.com/article /10.1007\%2Fs00253-011-3777-2>. Accessed: Ago. 11, 2013. doi: $10.1007 / \mathrm{s} 00253-011-3777-2$

FERREIRA-DIAS, S. et al. Comparison between ethanol and hexane for oil extraction from Quercus suber L. fruits. Grasas y Aceites, v.54, p.378-383, 2003. Available from: <http:// grasasyaceites.revistas.csic.es/index.php/grasasyaceites/article/ viewArticle/225>. Accessed: Ago. 11, 2013. doi:10.3989/ gya.2003.v54.i4.225.

GATESOUPE, F.J. Live yeasts in the gut: natural occurrence, dietary introduction, and their effects on fish health and development. Aquaculture, v.267, p.20-30, 2007. Available from: <http://archimer.ifremer.fr/doc/2007/publication-2144. pdf>. Accessed: Ago. 11, 2013. doi: 10.1016/j. aquaculture.2007.01.005.

KAVITHA, C. et al. Toxicity of Moringa oleifera seed extract on some hematological and biochemical profiles in a freshwater fish, Cyprinus carpio. Experimental and Toxicologic Pathology, v.64, p.681-687, 2012. Available from: <http://www.sciencedirect. 
com/science/article/pii/S0940299311000029>. Accessed: Ago. 11, 2013. doi: 10.1016/j.etp.2011.01.001.

MACIEL, C.R.; VALENTI, W.C. Biology, fisheries, and aquaculture of the amazon river prawn Macrobrachium amazonicum: a review. Nauplius, v.17, p.61-79, 2009. Available from: <http://www.crustacea.org.br/artigos/151_20_01__maciel_ valenti.pdf $>$. Accessed: Jan. 23, 2013.

MEDEIROS, A.O. et al. Water Research, v.42, p.3921-3929, 2008. Available from: <http://www.sciencedirect.com/science/ article/pii/S0043135408002522>. Accessed: Ago. 13, 2013. doi: 10.1016/j.watres.2008.05.026.

MEYER, B.N. et al. Brine shrimp: a convenient general bioassay for active plant constituents. Journal of Medicinal Plants Research, v.45, p.31-34, 1982. Available from: <https://www.thieme-connect. com/products/ejournals/abstract/10.1055/s-2007-971236>. Accessed: Ago. 13, 2013. doi: 10.1055/s-2007-971236.

OKUDA, T. et al. Isolation and characterization of coagulant extracted from Moringa oleifera seed by salt solution. Water Research, v.35, p.405-410, 2001. Available from: <http://dx.doi. org/10.1016/S0043-1354(00)00290-6>. Accessed: Jun. 13, 2013.

PETROVIC, U. et al. Cellular responses to environmental salinity in the halophilic black yeast Hortaea werneckii. Molecular microbiology, v.45, p.665-672, 2002. Available from: <http:// onlinelibrary.wiley.com/doi/10.1046/j.1365-2958.2002.03021.x/ pdf>. Accessed: Jun. 15, 2013

PILLAI, D.; BONAMI, J.R. A review on the diseases of freshwater prawns with special focus on white tail disease of Macrobrachium rosenbergii. Aquaculture Research, v.43, p.1029-1037, 2012. Available from: <http://onlinelibrary.wiley.com/doi/10.1111/ j.1365-2109.2011.03061.x/abstract>. Accessed: Jun. 24, 2013. doi: 10.1111/j.1365-2109.2011.03061.x.

RAMOS, S.C.S. et al. Antibacterial and cytotoxic properties of some plant crude extracts used in Northeastern folk medicine. Brazilian Journal of Pharmacognosy, v.19, p.376-381, 2009. Available from: <http://dx.doi.org/10.1590/S0102-
695X2009000300007>. Accessed: Jun. 24, 2013. doi: 10.1590/ S0102-695X2009000300007.

RAHMAN, M.S. et al. Antibacterial and antifungal activity of Moringa oleifera stem bark. Chittagong University Journal of Biological Sciences, v.3, p.109-117, 2008. Available from: <http:// dx.doi.org/10.3329/cujbs.v3i1.13411>. Accessed: Jul. 23, 2013. doi: 10.3329/cujbs.v3i1.13411.

REBOUÇAS, R.H. et al. Antimicrobial resistance profile of Vibrio species isolated from marine shrimp farming environments (Litopenaeus vannamei) at Ceará, Brazil. Environmental Research, v.111, p.21-24, 2011. Available from: <http://www.sciencedirect.com/science/article/pii/ S0013935110001544>. Accessed: Jul. 30, 2013. doi:10.1016/j. envres.2010.09.012.

ROCHA, M.F.G. et al. Extratos de Moringa oleifera e Vernonia sp. sobre Candida albicans e Microsporum canis isolados de cães e gatos e análise da toxicidade em Artemia sp. Ciência Rural, v.41, p.1807-1812, 2011. Available from: <http://dx.doi. org/10.1590/S0103-84782011001000022>. Accessed: Jul. 12. 2013. doi: 10.1590/S0103-84782011001000022.

SÁNCHEZ-MARTÍN, J. et al. Comparison of single-step and two-step purified coagulants from Moringa oleifera seed for turbidity and DOC removal. Bioresource Technology, v.101, p.6259-6261, 2010. Available from: <http://dx.doi.org/10.1016/j. biortech.2010.02.072>. Accessed: Jul. 05, 2013. doi: 10.1016/j. biortech.2010.02.072.

SAHUL HAMEED, A.S. et al. Antibiotic resistance in bacteria isolated from hatchery-reared larvae and post-larvae of Macrobrachium rosenbergii. Aquaculture, v.217, p.3948, 2003. Available from: <http://dx.doi.org/10.1016/S00448486(02)00298-3>. Accessed: Jul. 18, 2013.

TIWARI, S.; SINGH, A. Control of common freshwater predatory fish, Channa punctatus, through Nerium indicum leaf extracts. Chemosphere, v.53, p.865-875, 2003. Available from: <http:// dx.doi.org/10.1016/S0045-6535(03)00595-2>. Accessed: Jul. 03, 2013. doi: 10.1016/S0045-6535(03)00595-2. 